\title{
Torquálódott méhfüggelék laparoszkópos ellátása a 32. terhességi héten
}

\author{
Vincze Márió Attila dr. - Németh Gábor dr. - Novák Tibor dr. \\ Szegedi Tudományegyetem, Általános Orvostudományi Kar, Szülészeti és Nőgyógyászati Klinika, Szeged
}

Terhességben az élettani és anatómiai változások miatt bizonyos patológiás szervi eltérések nem specifikus tünettannal járhatnak. A várandósság alatt fellépő hasi panaszok esetén lényeges felállítani a gyors és pontos diagnózist, a minél korábbi adekvát terápia érdekében. A klinikai tünetek hátterében többek között állhatnak szülészeti betegségek, illetve appendicitis, megnagyobbodott ovariumcysta, nephrolithiasis vagy diverticulitis is. Esetismertetésünkben egy 32 hetes gravida ellátását prezentáljuk, aki jobb alhasi panaszok miatt jelentkezett a Szegedi Tudományegyetem Szülészeti és Nőgyógyászati Klinikáján. A magzati paraméterek megfelelőek voltak. A klinikai vizsgálatok appendicitis gyanúját vetették fel, mely miatt laparoszkópia történt. Torquálódott jobb oldali tuba uterina miatt jobb oldali salpingectomiát végeztünk, az appendix kóros elváltozása nem igazolódott. Magzati, illetve anyai szövődmény a posztoperatív szakban nem volt. A további terhesgondozás során szövődményt nem észleltünk, majd a betöltött 40. terhességi héten hüvelyi úton egészséges újszülött született. A méhfüggelék megcsavarodásának operatív megoldása laparoszkópos úton alkalmazható módszernek tekinthető terhességben is. Az adnexcsavarodás ritka sürgősségi nőgyógyászati kórképnek számít, bár szakirodalmi adatok alapján az adnexum torsiójának rizikója fokozott lehet a terhesség korai szakaszában, kiváltképp asszisztált reprodukciós technikák alkalmazása esetén. Várandósság alatt hirtelen jelentkező alhasi panaszok esetén az anamnesztikus adatok tükrében, a klinikai vizsgálatok során szükséges az adnextorsio lehetőségére is gondolni.

Orv Hetil. 2021; 162(35): 1418-1421.

Kulcsszavak: adnextorsio, paratubaris cysta, terhesség, laparoszkópia

\section{Laparoscopic management of adnexal torsion at 32th week of gestation}

Due to physiological and anatomical changes in pregnancy, certain pathological organ abnormalities may be associated with non-specific symptoms. In the case of abdominal complaints during pregnancy, it is important to make a quick and accurate diagnosis to apply an early adequate therapy. The cause of the clinical symptoms can be obstetrical diseases, appendicitis, large ovarial cyst, rarely nephrolithiasis or diverticulitis. Through our case study, we present the treatment of a 32-week gravida. Examination of the pregnant patient occured at the Department of Obstetrics and Gynecology of the University of Szeged due to right lower abdominal pain. The fetal parameters were satisfactory. We assumed appendicitis, so after proper preparation laparoscopy was performed. Salpingectomy was performed because of torqued right fallopian tube and no pathological changes were detected on the appendix. In the postoperative period, there were no fetal or maternal complications. During further care of pregnancy, there were no complications and a healthy newborn was born by vaginal delivery at the 40th week of gestation. The operative procedure of adnexal rotation by laparoscopy can be considered as an applicable method even in pregnancy. Adnexal torsion is a rare emergency gynecological disease, although literature data suggest an increased risk in early pregnancy, especially in the case of assisted reproductive technology. In the case of sudden abdominal pain during pregnancy, in the light of anamnestic data, it is recommended to consider the possibility of adnexal torsion, too.

Keywords: adnexal torsion, paratubal cyst, pregnancy, laparoscopy

Vincze MA, Németh G, Novák T. [Laparoscopic management of adnexal torsion at 32th week of gestation]. Orv Hetil. 2021; 162(35): 1418-1421.

(Beérkezett: 2021. január 5.; elfogadva: 2021. február 18.) 


\section{Rövidítések}

HELLP-szindróma $=$ (hemolysis, elevated liver enzymes, low platelet count syndrome) vörösvértestek szétesésével, emelkedett májenzimszinttel és alacsony vérlemezkeszinttel járó szindróma; IVF = in vitro fertilizáció; $\mathrm{MR}$ = mágneses rezonancia

Adnextorsio alakul ki, ha az ovarium és a tuba uterina megcsavarodik a ligamentum infundibulopelvicum és a ligamentum ovarii proprium tengelye körül. Ez az állapot vascularis kompresszióhoz és az adnexum necrosisához vezethet. Elmondható, hogy a nőgyógyászati sürgős esetek 2-3\%-ában fordul elő [1]. Incidenciája terhességben 1,6/10 000 [2]. A kórkép egyébként már gyermekkorban kialakulhat, és korai felismerése elsődleges az adnexum lehetőség szerinti megtartását illetően [3]. Peripubertalis korban a fel nem ismert polycystás ovarium szindrómával összefüggésben nagyobb eséllyel alakulhat ki az adnexum torsiója, mint felnőtt populációban [4]. A terhesség fokozott rizikót jelenthet az adnextorsiót illetően, kiváltképp asszisztált reprodukciós kezeléssel összefüggésben [5-8]. Várandósság alatt kóroki tényezők lehetnek különböző ovarialis képletek vagy paratubaris cysta is. A ligamentum ovarii proprium hipermobilitása és hossza miatt gyakoribb a jobb adnexum torsiója [6].

A tünetek nem specifikusak, előfordulhat hirtelen jelentkező fájdalom az érintett oldalon, hányinger, hányás, hasi nyomásérzékenység és lokalizált défense, lázzal vagy a nélkül. Nincs specifikus laboratóriumi markere, a gyulladásos paraméterek emelkedhetnek (leukocytosis, C-reaktív protein, prokalcitonin). Az akut panaszok megjelenése ischaemiára utal, mely ha állandósul, a tuba uterina és az ovarium necrosisát okozhatja. Ultrahangképe változatos lehet, függ az eltelt időtől: ovariumcysta vagy -képlet abnormális pozícióban, szabad hasüri folyadék megjelenése, megnagyobbodott és oedemás ovarium. Doppler-vizsgálattal magas pozitív prediktív értékkel bír az artériás és a vénás áramlás hiányának jele, bár a megtartott áramlás nem zárja ki az adnextorsio lehetôségét $[7,9]$. Differenciáldiagnosztikai szempontból szóba jöhetnek szülészeti betegségek (uterusruptura, abruptio placentae, HELLP-szindróma), illetve appendicitis, ovarialis cysta ruptura, nephrolithiasis, sigmadiverticulitis, melyeket fizikális status, képalkotó diagnosztika, laborparaméterek, végső esetben műtéti diagnosztika alapján tudunk elkülöníteni.

Kezelése sebészi; ha necrosis nem észlelhető, a derotatiót szükséges elvégezni. Súlyos esetben salpingectomiát, oophorectomiát vagy adnexectomiát szükséges végezni, mely történhet laparotomiából vagy laparoszkópos úton.

\section{Esetismertetés}

A tanulmányban egy 35 éves, 32 hetes, harmadszor szülő, előzetesen császármetszésen átesett gravida esetét ismertetjük. Az első szülés császármetszés útján történt magzati medencevégú hosszfekvés miatt, majd néhány évvel később a második szülés hüvelyi úton zajlott le. Mindkét esetben érett, egészséges újszülöttjei születtek. Kórtörténetében egy jobb oldali dermoid cysta laparoszkópos eltávolítása szerepel az első szülést megelőzően. A jelen terhessége spontán fogant, szövődménymentesen zajlott. A gravida jobb alhasi fájdalommal járó panaszok miatt jelentkezett a Szegedi Tudományegyetem Szülészeti és Nőgyógyászati Klinikáján. Panaszai aznap hirtelen jelentkeztek. Hányingert, hányást nem panaszolt, láza nem volt, vitális paraméterei megfelelőek voltak. A fizikális vizsgálat során jobb alhasi nyomásérzékenységet jelzett, kóros terime nem volt tapintható, défense nem volt észlelhető. Laboratóriumi leleteiben enyhén emelkedett C-reaktív protein $(6 \mathrm{mg} / \mathrm{l})$ és fehérvérsejtszám (14 G/1) volt detektálható. Intrauterin distresszre utaló jel nem igazolódott; a biometriai vizsgálat során a magzat a terhességi kornak megfelelt, a magzatvizet átlagos mennyiségűnek ítéltük, placentaleválásra utaló jel nem volt látható. Méhtevékenységet nem regisztráltunk, a cervix zárt, 48 milliméter hosszú volt. Tekintettel arra, hogy szülészeti szempontból teendő nem igazolódott, további ellátás céljából a Sürgősségi Betegellátó Osztályra irányítottuk differenciáldiagnosztikai kivizsgálásra. A hasi ultrahangvizsgálat jobb oldali diszkrét pyelectasiát és a pericaecalis régióban $8-10 \mathrm{~mm}$ szabad hasúri folyadékot jelzett, mely a másnapi kontroll-ultrahangvizsgálaton progressziót nem mutatott. Az appendix nem volt látótérbe hozható. A kontroll-laborvizsgálat a C-reaktív protein emelkedő tendenciájú, nem markáns emelkedését $(9,4 \mathrm{mg} / \mathrm{l})$, közel stagnáló fehérvérsejtszámot $(13,4 \mathrm{G} / 1)$ és a normáltartományon belüli prokalcitoninszintet $(<0,05 \mathrm{ng} / \mathrm{l})$ igazolt. Az appendicitis kizárására sebészeti konzílium történt, a vizsgálat során a várandós a jobb alhas területén jelzett nyomásérzékenységet. Défense, peritonealis izgalmi jel nem volt észlelhető. Az appendicitis segédtünetei nem voltak megítélhetők. Közepesen élénk bélhangokat detektáltak, a sérvkapukat szabadnak ítélték meg.

Tekintettel arra, hogy a terhes panaszai továbbra is fennálltak, az azok jelentkezésétől számított második napon laparoszkópia elvégzése mellett döntöttünk appendicitis gyanúja miatt. Epigastrialis medián behatolást követően 2 liter szén-dioxid-insufflatiót végeztünk, majd a $30^{\circ}$-os optika bevezetése történt a metszésnek megfelelő porton keresztül. A has áttekintését követően a köldök felett és jobb oldalon subcostalisan további két segédport került bevezetésre. A jobb oldalon ép ovarium mellett torquálódott, részben nekrotizált petevezeték igazolódott, így az érintett oldalon salpingectomiát végeztünk, majd a tuba uterina eredésénél klipek kerültek felhelyezésre. Az appendixen eltérés nem volt észlelhető. A mütéti beavatkozás 65 percig tartott.

A várandós a posztoperatív időszakban per os tocolysisben és thrombosisprofilaxisban részesült. Terhességét monitorizáltuk, majd a mütétet követő 7 . napon panaszmentesen, megtartott terhességgel emittáltuk. A továb- 
biakban a várandósgondozási protokoll szerinti ellátásban részesült, melynek során anyai vagy magzati szövődmény nem merült fel.

A hisztológiai lelet a jobb oldali tuba uterina akut vérzéses infarktusát igazolta paratubaris cysta jelenlétével. A mesothelrétegen néhol fibrines exsudatio nyomait észlelték. Atypia, malignitás jelei nem voltak láthatók.

Zavartalan terhességet követően 40 hét 6 napos gestatiós korban per vias naturales élő, érett fiú újszülött született 10-es Apgar-értékú állapotban. Az édesanya a szülést követő 3. napon panaszmentesen, újszülöttjével otthonába távozott.

\section{Megbeszélés}

$\mathrm{Az}$ adnexcsavarodás mint nőgyógyászati kórkép relatíve ritka betegségnek számít, bár számos szakirodalmi közlemény alapján elmondható, hogy a terhesség jelentős rizikófaktor lehet az adnextorsiót tekintve: a vizsgált esetek akár 8-27\%-ában előfordulhat [10-14]. Fokozott kockázatot jelenthet továbbá az ovulációindukció, az ovarium-hiperstimulációs szindróma, a polycystás ovarium szindróma, az anamnézisben szereplő korábbi adnextorsio vagy petevezetéken végzett műtét [7]. Szakirodalmi adatok alapján a megelőző császármetszés nem sorolható egyértelműen a rizikófaktorok közé $[5,8,15$, 16].

Adnextorsio elsősorban az 1. trimeszterben és a kora 2. trimeszterben fordul elö, ritkábban jelentkezik a 3. trimeszterben $[1,2,5,16]$. Dvash és mtsai kohorsztanulmányban 94 várandóst vizsgáltak, ebből mindössze 2\%ban fordult elö adnextorsio a 3. trimeszterben [2]. Az anamnézisben az esetek 48\%-ában szerepelt in vitro fertilizáció (IVF) vagy ovulációindukció [2].

A preoperatív diagnózis megközelítóleg 40\%-ban kerül felismerésre, a pontos diagnózis mútét során állítható fel [1]. Terhességben a 2. és 3. trimeszterben az adnexumok ultrahanggal korlátozottan vizsgálhatók, így a diagnózis és a sebészi beavatkozás késhet, ami anyai és magzati szövődményekhez vezethet. Djavadian közleményében 38 beteg vizsgálata során a várandósok felvétele és operációja közötti idő szignifikánsan hosszabb volt a 2 . és 3. trimeszterben, mint az 1. trimeszterben, és 15\%ban helytelen volt a preoperatív diagnózis [17]. Terhességben a pontos diagnózis felállításához nagyban hozzájárulhat az MR-vizsgálat is [9].

Az adnextorsio kezelése sebészi, elsősorban az adnexum derotatiója, amennyiben indokolt, az adnexum patológiás részének eltávolítása (cystectomia, salpingectomia, oophorectomia) vagy adnexectomia végzendő. A terhességi kortól és az elváltozás súlyosságától függően a beavatkozás primeren laparoszkópos úton elvégezhető. Wang és Deng retrospektív tanulmányban 82 , igazolt adnextorsio miatt kezelt gravidát vizsgált; a mútéti megoldás 76,8\%-ban laparoszkópia, 23,2\%-ban laparotomia útján történt [5]. A medián gestatiós idő szignifikánsan magasabb volt a laparotomia útján operált várandósok esetében [5]. Daykan és mtsai 85 terhest vizsgálva 8,2\%ban az adnexcsavarodás mútéti megoldásaként a laparotomiát választották, a sebészi behatolás típusa független volt a gestatiós kortól [16].

\section{Következtetés}

A terhesség 3. trimeszterében alacsony gyakorisággal alakul ki adnexcsavarodás. A nem specifikus klinikai tünetek, illetve előrehaladott gestatiós korban az anatómiai és élettani változások lényegesen megnehezítik az adnextorsio diagnosztizálását. Differenciáldiagnosztikai szempontból lényeges a részletes anamnézisfelvétel; a szülészeti betegségek kizárását követően, a klinikai tünetek súlyosbodása esetén mielőbbi sebészeti beavatkozás végzendő. A betegség progressziója szeptikus anyai szövődményekhez, koraterhességben spontán vetéléshez, a 3. trimeszterben magzati elhaláshoz vezethet.

Összességében megállapítható, hogy terhességben az adnexcsavarodás miatt végzett laparoszkópia biztonságos eljárásnak tekinthető. Korai pontos diagnózissal és kezeléssel az ovariumok lehetőség szerint konzerválhatók. A terhességi kimenetelt és az újszülött állapotát a laparoszkópos beavatkozás nem befolyásolja szignifikánsan [2].

Anyagi támogatás: A publikáció megírásához a szerzők anyagi támogatásban nem részesültek.

Szerzôi munkamegosztás: V. M. A.: Az eset feldolgozása, szakirodalomi adatgyüjtés, a cikk megírása. N. G. és N. T.: Szakmai támogatás, a tanulmány szakmai és szerkezeti revíziója. A szerzők a cikk végleges változatát elolvasták és jóváhagyták.

Érdekeltségek: A szerzőknek nincsenek érdekeltségeik.

\section{Irodalom}

[1] Asfour V, Varma R, Menon P. Clinical risk factors for ovarian torsion. J Obstet Gynaecol. 2015; 35: 721-725.

[2] Dvash S, Pekar M, Melcer Y, et al. Adnexal torsion in pregnancy managed by laparoscopy is associated with favorable obstetric outcomes. J Minim Invasive Gynecol. 2020; 27: 1295-1299.

[3] Vass Cs, Nagy P. Adnexal torsion in childhood. [Függelékcsavarodás gyermekkorban.] Orv Hetil. 2001; 142: 1335-1336. [Hungarian]

[4] Ságodi L, Schmidt I, Vámosi I, et al. Peripubertal ovarian cyst torsion, as an early complication of undiagnosed polycystic ovarian syndrome. [Peripubertális petefészekciszta-torzió mint a fel nem ismert polycystás ovarium szindróma korai szövődménye.] Orv Hetil. 2013; 154: 113-117. [Hungarian]

[5] Wang YX, Deng S. Clinical characteristics, treatment and outcomes of adnexal torsion in pregnant women: a retrospective study. BMC Pregnancy Childbirth 2020; 20: 483

[6] Bouquet de Joliniere J, Dubuisson JB, Khomsi F, et al. Laparoscopic adnexectomy for ovarian torsion during late pregnancy: case report of a non-conservative treatment and literature analysis. Front Surg. 2017; 4: 50. 
[7] Sasaki KJ, Miller CE. Adnexal torsion: Review of the literature. J Minim Invasive Gynecol. 2014; 21: 196-202.

[8] Rottenstreich M, Rotem R, Hirsch A, et al. Maternal and perinatal outcomes following laparoscopy for suspected adnexal torsion during pregnancy: a multicenter cohort study. Arch Gynecol Obstet. 2020; 302: 1413-1419.

[9] Bai W, Xu X, Xie H, et al. Adnexal torsion in the third trimester of pregnancy: a case report and diagnostic value of MR imaging. BMC Med Imaging 2020; 20: 19.

[10] Houry D, Abbott JT. Ovarian torsion: a fifteen-year review. Ann Emerg Med. 2001; 38: 156-159.

[11] Bouguizane S, Bibi H, Farhat Y, et al. Adnexal torsion: a report of 135 cases. [Les torsions des annexes de l'utérus.] J Gynecol Obstet Biol Reprod. 2003; 32: 535-540. [French]

[12] Peña JE, Ufberg D, Cooney N, et al. Usefulness of Doppler sonography in the diagnosis of ovarian torsion. Fertil Steril. 2000; 73: 1047-1050

[13] Balci O, Icen MS, Mahmoud AS, et al. Management and outcomes of adnexal torsion: a 5-year experience. Arch Gynecol Obstet. 2011; 284: 643-646.
[14] Descargues G, Tinlot-Mauger F, Gravier A, et al. Adnexal torsion: a report on forty-five cases. Eur J Obstet Gynecol Reprod Biol. 2001; 98: 91-96.

[15] Lo LM, Chang SD, Horng SG, et al. Laparoscopy versus laparotomy for surgical intervention of ovarian torsion. J Obstet Gynaecol Res. 2008; 34: 1020-1025.

[16] Daykan Y, Bogin R, Sharvit M, et al. Adnexal torsion during pregnancy: outcomes after surgical intervention - a retrospective case-control study. J Minim Invasive Gynecol. 2019; 26: 117121.

[17] Djavadian D, Braendle W, Jaenicke F. Laparoscopic oophoropexy for the treatment of recurrent torsion of the adnexa in pregnancy: case report and review. Fertil Steril. 2004; 82: 933-936.

(Vincze Márió Attila dr., Szeged, Semmelweis u. 1., 6725 e-mail: vincze.mario.attila@med.u-szeged.hu)

\section{„Operatio non sit gravior ipso morbo." (A műtét nem lehet veszélyesebb magánál a betegségnél.)}

A cikk a Creative Commons Attribution 4.0 International License (https://creativecommons.org/licenses/by/4.0/) feltételei szerint publikált Open Access közlemény, melynek szellemében a cikk bármilyen médiumban szabadon felhasználható, megosztható és újraközölhető, feltéve, hogy az eredeti szerző és a közlés helye, illetve a CC License linkje és az esetlegesen végrehajtott módosítások feltüntetésre kerülnek. (SID_1) 